\title{
Aantekeninge/Notes
}

\section{The timeous enforcement of trade mark rights}

\section{Introduction}

Ideally, a trade mark proprietor should take steps to enjoin infringing use as soon as possible after a third party commences use of a registered trade mark, such use amounting to infringement. The reality of commerce is, of course, that this does not always happen. Sometimes the proprietor might simply not be aware of the infringement. At other times the third party's use could be perceived not to be prejudicial at first, due to, inter alia, geographical considerations, the size of the operation, the nature of the goods produced or services rendered etc. The result could be that court proceedings are only instituted a number of years after use first began (but always on the assumption of course that the third party's use postdates the registration date of the proprietor's mark). By way of example, in Turbek Trading CC $v$ A \& D Spitz Ltd 2009 (SCA) 158, a claim was considered on the merits despite a delay of six years (par 15). One question that needs answering here is what the legal consequences are when there is a delay before a trade mark right is enforced. Another, in what circumstances the delay can constitute a defence, and the various defences that could feature (waiver and consent are not dealt with here - see Sonnekus The Law of Estoppel in South Africa (2012) 161). These issues are discussed below (see also Alberts 'Check who's using your trade mark: The need for the timely enforcement of trade-mark rights' 2007 Juta's Business Law 32).

\section{Relevant Situations}

\section{Honest Concurrent Use (HCU)}

Does a period of undisturbed use benefit the third party trade mark user mentioned above in a registration context? One scenario that can occur is that an application will be refused by the Registrar of Trade Marks, based on a conflict with a prior registered mark (s 10(14) of the Trade Marks Act 194 of 1993). Unless this citation is removed, the application will not proceed to registration. However, the Register may withdraw the citation in the event of HCU having taken place and "register" the mark (s 14(1)). The general factors which should be considered in HCU matters were set out in the British decision of Pirie's Application 1933 RPC 147. These include contingencies of confusion, whether the choice of the mark was honestly made, the nature of the trades of the respective parties, actual confusion, and, importantly, the duration of use (159 line

How to cite: Alberts ‘The timeous enforcement of trade mark rights' 2015 De Jure 172-181 
$47-160 \&$ line 12). A period of use of eight years was for instance accepted in Ex parte Chemisch-Pharmazeutische Aktiengesellschaft 1934 (TPD) 366. In so far as the British Registrar's previous practice is concerned, reference can be made to his Working Manual (Journal No 6171, ch 6, par 11.17.2; own emphasis):

As a starting point, the mark should have been in use for a reasonable period, usually about five years, prior to the application date. This means the other party, against which the applicant is claiming honest concurrent use, has a reasonable time in which to become aware of the applicant, and to make any challenge. It must be stressed however, that this period is only a guideline. Where circumstances dictate otherwise, this period can be reduced (or, indeed, increased). It may be possible to reduce this period if e.g. the applicant has spent a massive amount on advertising his product and/or has had a very good turnover, even though his use only predates his application by a couple of years. Conversely, the period of use may need to be substantially more than five years, if the turnover is so small that it diminishes the weight that can be given to the length of use" (information available from: http://www.patent.gov.uk/tm/reference/workman/chapt6/ sec11 (17).pdf)

Currently, in the United Kingdom, the role of HCU in the examination stage of an application has been reduced, as an order was passed in 2007 which "means that honest concurrent use can no longer be filed in support of an application where there is a requirement to notify the owners of earlier marks thought to be confusable with the applicant's mark" (information available from: 22http://www.ipo.gov.uk/tmmanualchap3-exam.pdf). The emphasis in the above quotation, is on the opportunity the proprietor must have had to take steps against the potential infringer. Whether knowledge on the part of the proprietor is required in our law is unclear, and the British position might be adopted, although the view in practice is that knowledge is not required. Perhaps one can then say that where the proprietor is unaware, the relevant ground in section 14(1) is not HCU, but "special circumstances" (see in general Ex parte de Wet Bros (Pty) Ltd 1940 (CPD) 136; Origins Natural Resources Inc v Origin Clothing Limited 1995 (FSR) 280).

Knowledge on the part of the third party user might be exclusionary (Massachusetts Saw Works 1918 (RPC) 137148 line 13). It has however been held that knowledge of the registration of the opponent's mark may be an important factor where the honesty of the user of the mark sought to be registered is challenged, but when once the honesty of the user has been established the fact of knowledge loses much of its significance (Pirie case 159 lines 21-42). Lastly, it should be pointed out that if there is no confusion, the reason for the selection of a mark is no longer relevant. This approach is embodied in another decision, dealing with trade mark infringement, namely that in Red Bull GmbH $v$ Rizo Investments (Pty) Ltd Case number 25741/2001, decision of the then Transvaal Provincial Division, delivered on 28 June 2002. There the court stated the following (p 10): 
However if the charade is acted out successfully and the resemblance is not such as to be likely to deceive or cause confusion among potential purchasers of the products, then the reason why the offending mark was chosen is irrelevant.

\section{The Absence of Confusion}

The issue of confusion is central to most trade mark conflicts. This also applies to the common law remedy of passing off. In order to rely on the latter, it is a requirement that at least the likelihood of confusion must be established (Van Heerden \& Neethling Unlawful Competition (2008) 181). Evidence of actual confusion is not required. The same applies to statutory trade mark infringement. Section 34(1)(b) of the Trade Marks Act deals with use in relation to similar goods, wherein "use there exists the likelihood of... confusion". Likewise, section 10(12) and 10(14), dealing with oppositions on the basis of common law rights, and a registration, respectively, both require the likelihood of confusion. Proof of actual confusion is not required. However, in decisions such as that in Arsenal Football Club PLC v Reed (2001 (RPC) 922) it was said that "absence of evidence of confusion becomes more telling and more demanding of explanation by the claimant the longer, more open and more extensive the defendant's activities are" (par 24).

In Phones 4U Ltd $v$ Phone 4u. co uk Internet Ltd 2007 (RPC) 83 it was said that the absence of evidence of confusion "gives rise to a powerful inference that there is no ... confusion" (par 42). This principle was described in colourful language, in the latter decision, by a witness who said that the absence of evidence of confusion was a case where "the dog did not bark". The court commented in this regard that the extent of use will determine whether the inference of an absence of confusion can be drawn, and stated that "[y]ou have to show [that] there is a dog who could have barked" (par 43). Other views also exist. In Ratiopharm Gmbh's Trade Mark Application 2007 (RPC) 630 reference was made to case law to the effect that the lack of evidence of actual confusion is "rarely significant", as it may be due to differences extraneous to the registered mark (par 15). Also, the approach that absence of evidence of actual confusion shows that there is not a likelihood of confusion, is no more than a rule of thumb (par 15). Further, in the South African case of Adidas AG v Pepkor Retail Limited 2013 (SCA) 3 it was said that there is no significance that attaches to the absence of evidence of confusion (par 27). It would seem though, nevertheless, that the extent and duration of undisturbed side-by-use can be relevant (Webster \& Page South African Law of Trade Marks (1997) 7-19). It is suggested that the approach of the Arsenal case is more in line with practical reasoning. To this extent a considerable period of use will be to the advantage of the user. 


\section{Acquiescence}

In some jurisdictions the issue of acquiescence is regulated by statute. In the United Kingdom, for instance, section 48 of the Trade Marks Act of 1994 states the following:

(1) Where the proprietor of an earlier trade mark or other earlier right has acquiesced for a continuous period of five years in the use of a registered trade mark in the United Kingdom, being aware of that use, there shall cease to be any entitlement on the basis of that earlier trade mark or other right -

(a) to apply for a declaration that the registration of the later trade mark is invalid, or

(b) to oppose the use of the later trade mark in relation to the goods or services in relation to which it has been so used,

unless the registration of the later trade mark was applied for in bad faith.

Importantly, infringement proceedings can thus not be instituted. Notable is the requirement that the proprietor must have been aware of the use concerned. The scope of use or any pending negotiations are also relevant factors in terms of case law. The issue of acquiescence (and estoppel), featured in those contexts in Britain in Boxing Brands Ltd $v$ Sports Direct International plc (2013 (EWHC) 2200 (Ch)). Here the defendants argued that the claimant permitted them to build up a goodwill in the mark concerned. It was said that it would be unconscionable to prevent them from making use of that goodwill in future. The contention was rejected (par 123):

First I am far from satisfied that anything was done in the relevant period which built up any goodwill at all. The sales of gloves and other equipment was truly trivial. The usage of the QUEENSBERRY BOXING 1867 logo at fights might have built up some recognition but I am not satisfied about what that recognition would have related to. Second, the major steps relied on were undertaken at a time and in a context in which both sides were working toward coming to a mutual agreement. The fact the agreement was not reached does not make it unconscionable for either party to rely on their underlying legal rights. Third, the position was made clear by the claimant's letter of March 2012. The benefit of any permission or acquiescence by the claimant or its predecessors was terminated by that letter. I reject the defence based on acquiescence or estoppel.

A similar provision to said article 48(1) is found in article 9(1) of the European Council Directive No 89/104/EEC (repealed by EU Directive 2008/95/EC to approximate the laws of the Member States relating to trade marks). This provision featured in the decision of Budéjovicky Budvar, národni podnikv Anheuser-Busch Inc, Case C482/09, judgment of the Court of Justice of the European Union, dated 2011-09-22, where both parties obtained registration on the basis of HCU. An attack on the basis of prior use was however launched. The court remarked, amongst others, that the concept "acquiescence" differs from the word consent, which involves an intention to renounce a right which is unequivocally 
demonstrated (par 43). "Acquiescence", in contrast, means that someone remains inactive when faced with a situation in which he would be in a position to oppose (par 44).

With regard to English law, reference can be made to Daimler Chrysler AG v Javid Alavi (t/a Merc) 2001 RPC 813 where the defendant had used the trade mark Merc in relation to clothing for 30 years without instances of confusion. The court stated that mere delay does not form a ground of defence, unless it gives rise to a defence in terms of trade mark legislation, or amount to acquiescence. The view that mere delay, without more, can be no bar to the exercise by the owner of a registered trade mark of his statutory right, was accepted as correct (par 112). It was found that (par 113, own emphasis):

It is an essential component in a defence of acquiescence that the failure of the claimant to act should have induced the defendant to believe that the wrong was being assented to. But in this case there was no such reliance by Mr Alavi: indeed, he only remembered the visit to the stand on being asked by his solicitors, and had attached no importance to it at the time. In any event, DaimlerChrysler (or their predecessors) were not aware of his trading activities until 1997. These facts cannot support a plea of acquiescence. But the period of trading is very long. Had I found that Mr Alavi had infringed one or more of the Mercedes marks, but that there was no passing-off, and that there had been no damage, perhaps the question of delay should have to be considered in the context of relief. But the question does not arise. This defence fails.

In South Africa, in Policansky Brothers $v$ Hermann \& Cannard 1910 (TPD) 1265 it was remarked that it would be inequitable for a person to lay by for a "considerable" time (page 1281). In William Grant \& Sons Ltd v Cape Wine \& Distillers Ltd 19903 SA 897 (C) (the Grant case), the plaintiff was said to be barred from instituting proceedings in view of the delay that occurred after they became aware of the use of the defendant. The court attached weight to the fact that, initially, the defendant's position in the market did not threaten the plaintiff. It was accepted that, hypothetically, action at a later stage, once the defendant became a leading brand, whilst originally being an insignificant part of the market for some years after its launching, was in order. The test was said to be $(923 \mathrm{H})$ :

It was for defendants to show that their invasion of plaintiffs' right had been, for a sufficiently appreciable number of years, substantial enough to justify (and indeed require) the institution of proceedings by plaintiffs, if an end was to be put to defendant's unlawful competition.

It was also said that "the mere lapse of a number of years during which plaintiffs took no action does not in itself justify a finding of acquiescence on their part" (924A). It may be appropriate to state that the nature of the passing off concerned, namely a misrepresentation as to the origin of the goods, may have influenced the court. The approach where there is a (mere) inter partes dispute leading to confusion, but not deception, as in this case, could be different. It must be pointed out that it does not 
appear equitable, with respect, to allow a plaintiff to adopt a "wait and see" attitude to determine if, in effect, the defendant's business will prosper.

The appropriate status of the acquiescence defence was placed in perspective by Harms DP in Turbek Trading CC $v$ A \& D Spitz Ltd (supra par 15, own emphasis):

Turbek's first line of defence was a reliance on what counsel referred to as an 'equitable defence' of delay: if a party delays in enforcing its rights the party may in the discretion of the court either forfeit the rights or be precluded from enforcing them. The factual basis of the defence was, briefly put, that Spitz had known since 1 October 2001 of Turbek's trade mark applications and its use of the mark ' $\mathrm{KG}$ ' on footwear but only took steps to enforce its alleged common-law rights when it instituted the present proceedings during July 2007. This delay, according to the submission, amounted to acquiescence which disentitled Spitz from attacking the registrations or obtaining an interdict. Counsel relied on a statement by Patel J that our law recognises a defence of acquiescence distinct from estoppel and that the doctrine can be applied to halt cases where necessary to attain just and equitable results (Botha $v$ White). That Patel $\mathrm{J}$ had failed to take account of binding authority that contradicted his bald statement and that he had misread authority on which he sought to rely was pointed out by Thring J in New Media Publishing (Pty) Ltd v Eating Out Web Services CC... During argument it became clear that counsel was unable to contend more than that delay may in a suitable case be evidence of an intention to waive, evidence of a misrepresentation that might found estoppel, or evidence of consent for purposes of the volenti non fit injuria principle. In other words, counsel was unable to substantiate his submission that acquiescence is a substantive defence in our law. Delay, in the context of trade mark law, may provide evidence of a loss of goodwill or distinctiveness but that was not Turbek's case on the papers.

In other words, acquiescence is not a defence separate from estoppel, practically a case for estoppel must, accordingly, be made out. Delay may be relevant though in other respects (to be dealt with in part 3 below).

\section{Estoppel}

Another ground that may feature is estoppel. Estoppel is defined as follows by Sonnekus (supra 2):

The doctrine of estoppel by representation as applied in the courts of South Africa may generally be said to consist of the following. Where a person (the representor) by his words or conduct makes a representation to another person (the representee) and the latter, believing in the truth of the representation, acts thereon and would suffer prejudice if the representor were permitted to deny the truth of the representation made by him, the representor may be estopped - that is precluded, - from denying the truth of his representation.

The person that has used a trade mark (B) and wishes to rely on estoppel to ward of an infringement action by the proprietor of a registered mark (A), will have to overcome certain obstacles. Amongst 
others, there would have to be proof of a (mis)representation. Silence (or inaction by A) can indeed, in certain circumstances, amount to a representation (Sonnekus supra 165). Also required, is that A must have had a duty to speak. In other words, A should have foreseen that B would have made the wrong inference from A's "silence" and acted to his prejudice (Sonnekus supra 165). This introduces the issue of negligence. Negligence would require an answer to the question whether the reasonable person in the circumstances would have foreseen prejudice to a third party and would have taken steps to prevent detrimental consequences (Sonnekus supra 243). In the situation under discussion, this would inevitably involve questions as to the period of inaction. Periods of a few years usually feature. Significantly, in Oriental Products (Pty) Ltd v Pegma 178 Investments Trading CC (20112 SA 508 (SCA)), it was held that inaction for a mere two months was sufficient to constitute negligence (par 21). Should A have been aware of B's use, before B can rely on estoppel? There is case law to the effect that a person can by his negligence be estopped from contending that he was not aware of the nature and contents of a document signed by him (Sonnekus supra 249 $n$ 50). So A could not necessarily rely on the fact that he was not aware of B's use of the trade mark. On the other hand, in favour of A, is the approach, as per Grobler NO v Boikhutsong Business Undertaking (Pty) Ltd 19872 SA 547 (B) that there cannot be a misrepresentation if ownership (of immovable property) can be established from official records (562A). This view would, naturally, apply to intellectual property and the Register of Trade Marks, in the case of registered marks of course. However, mere knowledge by B of A's registered mark is not always the decisive factor. So, when A informs B that he has no objection to B's use, and A changes his position and object, for instance after obtaining legal advice, B could raise the estoppel defence (Webster \& Page supra 12-84). In summary, what might be decisive in estoppel cases, is whether a representation was made. In this regard it is worth noting and adapting what was said in the Grant case, being that "[t]he mere lapse of a number of years during which plaintiffs took no action does not in itself justify a finding of acquiescence on their part" (924A). In other words, such circumstances do not necessarily constitute a representation in the context of estoppel.

\section{Substantive Defence/Procedural Remedy}

\section{Staying of Infringement Proceedings}

In the above, consideration was given to the circumstances in which a third party user could have a defence based on the fact that an infringement action was not instituted timeously. One issue discussed was the position of the honest concurrent user (see Alberts 'Substantive and procedural facets of honest concurrent use in South African trade mark law' 2010 SALJ 339 341). What approach is followed in infringement proceedings, when the "defence" of concurrent right is raised? In the British case of Second Sight Ltd $v$ Novel UK Ltd 1995 (RPC) 423, the court stated that it would be a requirement for a stay of 
proceedings for the applicant for registration to have a seriously maintainable claim to registration and he must, furthermore, undertake to proceed with the application with all due diligence (434 line 44). In the South African case of Robertsons (Pty) Limited $v$ Pfizer SA (Pty) Limited 19673 SA 12 (T), A brought an application for an interdict against B, based on the alleged infringement of A's registered trademarks. B asked the court to defer the matter until an application for concurrent use in terms of the relevant legislation has been disposed of. The court refused, indicating that B would not be prejudiced (15C-E).

Likewise, according to Abdulhay M Mayet Group (Pty) Ltd $v$ Renasa Insurance Company Ltd 19994 SA 1039 (T), factors such as HCU or special circumstances do not constitute a statutory defence to infringement $(1048 \mathrm{G}-\mathrm{H})$. It was stated, however, that the court does have a discretion to stay infringement proceedings, but that discretion is to be exercised sparingly and only in exceptional circumstances $(1048 \mathrm{H}$ I). The rationale for this approach was described as follows (1048I1049A). It was said that the law of infringement will fall into desuetude if every infringer would be allowed to raise the defence that "I know that I am acting unlawfully, but bear with me; there is a possibility that my actions may become lawful". The proper route to follow would be to comply with the law and to desist from infringement until the application based on HCU is finalised. In Sidewalk Cafes (Pty) Ltd t/a Diggers Grill v Diggers Steakhouse (Pty) Ltd 19901 SA 192 (T), where the respondent had extensive use, it was held, in contrast, that the respondent did not have to await his application proceeding to registration on the basis of HCU, and was entitled to relief without delay (198J-199A). The province where the respondent conducted business in, was excised from the proprietor's registration. The factual bases in these matters might of course differ in relation to the scale of use.

\section{Interdict}

EU Directive 2008/95/EC in recital 12 states that:

It is important, for reasons of legal certainty and without inequitably prejudicing the interests of a proprietor of an earlier trade mark, to provide that the latter may no longer request a declaration of invalidity nor may he oppose the use of a trade mark subsequent to his own of which he has knowingly tolerated the use for a substantial length of time, unless the application for the subsequent trade mark was made in bad faith.

It was noted earlier that reliance on HCU in the United Kingdom required knowledge of the existence of the third party's activities by the proprietor. The position regarding acquiescence there, and in the European Union, is the same (the latter has no specific time period stipulated though), there must be awareness of the "infringer's" activities (s 48(1) of the British Trade Marks Act; Budějovický case (par 45)). Similarly in South Africa, in cases of estoppel, proof of knowledge on the part of the proprietor would assist the third party relying on estoppel. What is the situation though where there is no knowledge on the part of 
the proprietor? The third party might, to force the point, have been using the mark for ten years, but cannot, for argument's sake, make out a case for estoppel. Can the proprietor prevent the third party's continued use after all those years? Van Heerden and Neethling (supra 180) say that there is protection against a passing off action in comparable situations, if the mark has become distinctive of the goods of the third party. In the British Daimler case it was stated that (par 67; own emphasis):

I should just add that there must come a time after which the court would not interfere with a continued course of trading which might have involved passing off at its inception but no longer did so: logically, this point would come six years after it could safely be said that there was no deception and independent goodwill had been established in the market by the protagonist.

Also of interest, is the view of Wadlow (Law of Passing Off (2011) 856) who states that " $[\mathrm{t}]$ he distinctiveness of marks is frequently destroyed by conduct which would have been actionable, even fraudulent, had the plaintiff acted in time. A fortiori, a concurrent right to use the mark, or more properly an immunity, can thus be obtained by use which was less than honest in its inception".

What is the position though in a statutory milieu? In the Jalavi decision, it was remarked that the period of use was "very long", and it was added that "[h]ad I found that Mr Alavi had infringed one or more of the Mercedes marks, but that there was no passing-off, and that there had been no damage, perhaps the question of delay should have to be considered in the context of relief" (par 113). Similarly, in the Turbek ruling, Harms DP stated, after the quotation set out above, that his earlier explanation "does not mean that delay may not have procedural consequences; for instance, it may be a factor to take into account in exercising a court's discretion to refuse to issue ... an interim interdict or, maybe, even a final interdict, leaving the claimant to pursue other remedies such as damages" (par 15). One may infer from this that whilst delay is not a substantive defence, the eventual refusal of an interdict may, through a procedural mechanism, ensure a fair outcome.

The view of Harms DP will then also be in line with the British position. It has been stated there that delay might cause a court to refuse injunctive relief even if the conduct does not amount to acquiescence (Blackstone's Civil Practice 2013: The Commentary 614). Much would depend on the facts. So a two year delay might be excused, whilst a 20 days delay might cause relief to be refused (Blackstone's supra 615). In Blinkx UK Ltd $v$ Blinkbox Entertainment Ltd 2010 (EWHC) 1624 (Ch), a trade mark infringement and passing off matter, the plaintiff had operated a website providing an internet video service that gave access to film, television and video content. The respondent also had a website which offered its customers, amongst other things, the ability to choose, customise and share video and television clips. The court specifically rejected the argument that the plaintiff was entitled to wait for instances of confusion to occur in the marketplace (par 21). The court stated that "[h]ad the claimant acted promptly while the defendant's business was still in its 
trial phase, the balance of convenience might have favoured an injunction. But two years later it seems to me that the position has reversed" (par 28). The delay was held to be "fatal" (par 28).

What is the position where the proprietor is not aware of the use? It is submitted that the focus should not be exclusively on "punishing" the proprietor for not taking timeous action, whilst being aware of the third party's activities. In appropriate circumstances a court should thus refuse to grant an interdict of there has been an extensive period of open use.

\section{Conclusion}

In conclusion, where appropriate, relief can be provided to a third party user if there was an undue delay, albeit not by way of a substantive law principle. Principles of equity should also apply to cases where the proprietor was not aware of the third party's use.

RW ALBERTS

University of Johannesburg 